\title{
Application of Game Model Without Tool For Improving Locomotor Basic Movements In Elementary School Students
}

\author{
Muhammad Asrul \\ Postgraduate sport education \\ Universitas Negeri Medan \\ Medan, Indonesia \\ Muhammadasrul490@gmail.com
}

\author{
Tarsyad Nugraha, \\ Sport education courses \\ Universitas Negeri Medan \\ Medan, Indonesia
}

\author{
Indra Kasih \\ Sport education courses \\ Universitas Negeri Medan \\ Medan, Indonesia
}

\begin{abstract}
The suitability of the application of the learning model in the context of the teaching lesson is sometimes not in accordance with the characteristics of elementary school students, especially in the low class who have behaviors that are dominated by playing activities. For them, playing is his world. The application of the game model without tools in the learning process is not only to adjust the character of learning activities with the character of students. But through this game model, the psychomotor domain becomes clearly visible with the aim of increasing locomotor motion when students play and move. While the affective aspects are also expected to develop. One of them is associative behavior which consists of cooperation, accommodation and assimilation. The game model without tools is the main reference that can ensure the meaningfulness of playing models in order to develop basic locomotor movements of elementary students, especially low class.
\end{abstract}

Keywords - Learning Model Without Tools; physical education

\section{INTRODUCTION}

Physical education lessons in the world of education are included in one subject that is applied in every school, including in elementary schools. The implementation of physical education in elementary schools is very important, because at that age a child is in a period of physical growth and developing movement skills that play an important role in the initial formation to become qualified individuals later. Physical education provides an opportunity to be directly involved in various learning experiences through physical activity, playing, and exercising in a systematic, directed and planned manner.

According to Albadi and Nono a teacher must have a number of skills to be able to understand students and link these developments with the learning process, so that the teaching method can be implemented effectively [1]. Furthermore that the age of early children is the age of the game because most of the time is used to play.

Physical education teachers in primary schools must be able to use appropriate learning models to develop students' physicality, which must be based on the characteristics of children, so that the weaknesses in physical education in elementary schools can be overcome, in addition to the selection of materials must also be adapted to the conditions of primary school students, especially in low classes, namely grades one through third. But the reality is that this is not the case. Weakness in physical education is more in the inability of teachers to apply the learning model.

Thus it can be said by playing, the child's basic movements will develop, then followed by the development of motion ability. The development of this motion ability means that it must also be preceded by movement skills or in other words improve exercise skills and improve technical skills. The above is the main responsibility for Educators, especially the Teacher.

The development of locomotor basic motion in primary school-aged children includes being able to walk, run, be able to jump, jump and be able to maintain body balance, children are able to play jump rope, are able to play bicycles, in addition children also engage in sports activities that are formal like gymnastics and swimming.

Looking at the explanation above, the writer would like to make a paper about learning model entitled "Game Model Without Tools to Improve Basic Locomotor Movement in Low Grade Elementary Students".

\section{DISCUSSION}

Understanding Models and Games In general, the learning model is a method or technique of systematic presentation used by teachers in organizing the learning process experience to achieve the objectives of a learning. Furthermore, the definition of the learning model which means that the learning model is a plan or pattern used as a guide in planning learning in the classroom [2]. While the meaning of the learning model is the basis of the practice of learning resulting from a decrease in educational psychology theory [5] and learning theory designed based on an analysis of curriculum implementation and its implications at the operational level of the class, and added by Jihad and Haris which states that the learning model can be interpreted as a plan or pattern used in preparing the curriculum, arranging student material, and instructing the instructor in the classroom and in the teaching plan. The function of the learning model according to Aris is as a guide for teachers and teachers in carrying out teaching. 
Based on the expert opinion above it can be concluded that the learning model is a plan or pattern that is used as a practical basis for managing the curriculum, regulating the material of students, and providing guidance to teachers in the classroom and outside the classroom in planning teaching.

According to Pangrazi if a teacher chooses and evaluates a game that will be given to a child, it is necessary to pay attention to several things including: the skills needed, the number of children participating, complexity, the game / length of the game, and progress [6]. Children must receive positive feedback from the game experience. If in playing the game, the child feels bored and unhappy, then an evaluation is immediately carried out to find out the weaknesses and shortcomings of the game. Furthermore, according to Gabbard states that in choosing a game, it is necessary to pay attention to the points that must be applied. The points include:

a. Use game progress, from a small game form to the game team.

b. When choosing games, it is necessary to increase / advance the number and complexity of regulations and strategies

c. Use game situations to evaluate and improve affective behavior and also movement skills

d. Security must be the basis for consideration

e. Place the child in a formation and make instructions if possible.

f. Although participation is emphasized, if children's participation needs to be reduced, it is recommended that only one or two rounds

g. Avoid excessive emphasis in a competition

\section{Characteristics of Elementary Students}

Towards elementary school, children have developed acting thinking skills and more complex social influences. Up to this time, children are essentially egocentric (self-centered) and their world is a family home, and their childhood friends. During sitting in the lower grades of elementary school, children begin to be confident but also often inferior. At this stage they try to prove that they are "adults". They feel "I can do the work myself" they have been able to be given an assignment.

1. The age of entering the first grade of primary school is in the transition period from the rapid growth of early childhood to a slower phase of development. Child size is relatively smaller during the primary school changes.

2. The age of 9 years of height and weight of boys and girls are more or less the same. Before the age of 9 girls were relatively slightly shorter and slimmer than boys.

3. End of fourth grade, generally girls begin to experience a period of spike in arm and leg growth starting to grow fast.

4. At the end of fifth grade, generally girls are taller, heavier and stronger than boys. Boys begin to grow at around 11 years of age.
5. Towards the beginning of sixth grade, most girls approach the highest peak of growth. The puberty period which is characterized by menstruation generally begins at the age of 12-13 years. Boys enter puberty with ejaculation that occurs between the ages of $13-16$ years.

\section{Game Model Without Tools}

Games without tools are all game activities that do not require tools as a condition for the game. That is, without any special equipment, the game can still take place, what is required must only be a room that is wide enough so that children can play freely[5].

While the game with tools is a game activity that requires the existence of tools so that the game can take place. Even so, the necessary tools do not need expensive tools, let alone have to be limited by standard provisions which make it difficult. As an educational tool in Physical Education, a simple game with tools that are also simple can be chosen by the teacher, without reducing the solemnity and excitement of learning. Even with simple games, the benefits for children's physical, mental, emotional and social development can still be maximized. The following are examples of games without using tools, namely:

\section{Even Odd Games}

Game steps:

a. Tell students to line up and divide the 2 rows, then send the first row to form a circle, then send the second row to form the second circle (standing behind the first row).

b. Teacher or lecturer explains, if the coach mentions odd numbers, students must jump 2 times in the future. If the coach calls an even number, then the student must stay in place.

c. Tell the first row to face back, while the second row still faces ahead, so that fellow students don't clash with each other.

d. If the second row has begun to close, then the coach asks to change position. In the first row to face forward, while the second row to face back.

e. When the coach mentions odd and even numbers, there are students who do not concentrate so that they are wrong, then the student must advance to the center of the circle.

f. After the game is finished, for students who are wrong in the game will get a penalty from the coach.

\section{Dog and Cat Games}

Game steps:

a. Tell students to line up and divide into 3 rows, after which they are sent in the first row to form a circle. Then in the 2nd and 3rd row follow and stand behind the first row by forming a circle too.

b. Send 2 people to come forward.

c. One of them becomes a dog and someone becomes a cat. 
d. Dogs have to chase cats.

e. If the cat is tired of running, the cat can stop in front of the group in the circle.

f. When the cat has stopped in front of the line, the dog must chase the person in the back row where the cat stops at the group.

g. If a cat is caught by a dog, then the person who was originally a cat must change his position to become a dog and must pursue the next prey.

h. Position change

i. Cats no longer stop in front of the group line, but stop behind the rows of groups.

j. If the cat has stopped behind the group line, then the dog must chase the person who is at the front of the group where the cat stops.

\section{Cage and Bird Games}

Game steps:
a. Make 3 rows
b. The first and second rows become cages, where the first and second rows join hands and form a wide circle.
c. While the third row becomes a bird that must be inside the cage (in the middle of the cage).
d. When the coach blows the whistle and says "cage",
the bird must search and run to be / move to another
cage. If the coach says "bird", it is the cage who has to find / run to move to another bird.
e. If when the whistle is blown and there are still cages or birds that have not found a partner, then they must be in the middle of the circle to wait for other friends to be wrong and too late to get a partner. After that, birds and cages that do not get a partner will get punishment and must have a squat jump 5 times.

\section{Squirrel Vs Game Snake}

\section{Game steps:}

a. Divide students into 2 groups, A and B.

b. Students are asked to march bersaf by holding each other's hips.

c. The person who is at the very front is the snake's head that is in charge of protecting the snake's tail (the person who is at the very back of it so it cannot be reached by squirrels.

d. Each group must have squirrels by way of group A squirrels having to catch snake tails in group $\mathrm{B}$, while group B squirrels must catch snake tails in group A.

e. Participants who become squirrels must reach as many snakes as possible and the snake's head must guard the snake's tail without removing the handle.

f. If the squirrel from group A has caught the tail of a snake from group $\mathrm{B}$, then the person who has been captured immediately moves to group A to become the snake's tail in group A. The longest tail is the winner. And if one of the groups takes off the handle, it will be disqualified.

g. The loser gets punished, the squat jump 5 times.

\section{Game Relay Run}

Game steps:

a. Tell students to be 2 syaf and divided into 2 groups, Set the field line.

b. In the first person, groups A and B were confronted with each other's back, after which each of them ran to the corner (group A to the south and group B to the north). After that run back while still facing west. After arriving at the east line, change to run side position (group A goes north and group B goes south). After arriving in the middle of the field line, run forward to the west.

c. The next runner is at the start to wait for his turn to run. Likewise, then running turns to the last runner.

d. After the first runner arrives at the start line, the first runner crosses each other first to the person who has been waiting his turn to run. Then after that the next runner must also run in the same way.

e. This is done by all the children and the last person to get to the starting line faster, the group plagues the winner. But if one of the groups cheated by not following the rules, the cheating group will get punishment.

f. The loser gets a squat jump 5 times.

6. Game of Cats and Mice

Game steps:

a. Students are asked to make large circles and join hands.

b. The guide chose 2 people to become cats and 1 person became a rat.

c. Mice are in a circle, while 2 cats are outside the circle.

d. When there are cues starting, 2 cats chase mice, if the cat wants to enter the circle, then the children must be blocked.

e. If one of the cats reaches a mouse, the mouse must become a cat.

f. If the mouse becomes tired, then he can pat his friend, and the friend who is automatically patted becomes a rat

\section{The game frees captives}

Game steps:

a. Make a line that divides the room into two rooms

b. The teacher appoints two children to become guards and three children become soldiers.

c. Soldiers in parallel line occupy the first space near the dividing line, while the guard occupies the first space near the dividing line between the first and second spaces.

d. Other students as prisoners enter the second room.

e. After the teacher sounds a pluit, the army tries to purge the prisoner by bringing the prisoners out of the second room. 
f. The army can be said to be safe if it is not touched by the guard and survived by bringing the prisoner out of the second room.

g. The army can be said to be safe if it is not touched by the guards and survivors come out with prisoners.

h. If the soldier is not touched by the guards when entering and exiting the second room, then the prisoner can become a soldier, so that the army can increase and vice versa if entering the second room and returning to the first room is touched then the soldier will become a prisoner.

\section{CONCLUSION}

Short-term learning in elementary schools must pay attention to the characteristics of children so that the learning process can be maximized. Extension teachers need to know various types of learning models in order to be able to design and develop learning plans, especially in low class.

The ability of teachers in mastering the learning model will also facilitate the learning process so that children in elementary schools who are very fond of the game can be enthusiastic in learning while playing so that their basic motor skills are expected to increase.
A game without tools that is expected to be applied to improve students' basic movements is an odd-even game, group looking games, dog and cat games, cage and bird games, snake Vs snake games, relay running games, traffic light games, number notation games, games one, two, three, cat and mouse games, crown circle games, free prisoner games

\section{References}

[1] Albadi, dan Nono, 2014. Teori Dasar Motor Kontrol Dalam Pendidikan Jasmani dan Olahraga Pada Usia Dini. Medan: Unimed Press

[2] Trianto, 2009. Mendesain Model Pembelajaran Inovatif-Progresif. Jakarta: Kencana

[3] Shoimin Aris, 2016. 68 Model Pembelajaran Inovatif dalam Kurikullum 2013. Yogyakarta: Ar-Ruzz Media

[4] Soejoedi Imam, dkk, 1978. Permainan dan Metodik. Bandung: Tarate

[5] Agus Mahendra, 2005. Permainan Anak dan Aktivitas Ritmik. Jakarta: Universitas Terbuka

[6] Pangrazi, dkk. 1989. Dynamic Physical Education for Elementary School Children. (Nine Edition). USA: Macmillan Publishing Company. 